\title{
“Every Man His Own Publisher” \\ Extra-Illustration and the Dream \\ of the Universal Library
}

\author{
Gabrielle Dean
}

\begin{abstract}
In the twenty-first century, the age-old dream of a universal library seems within reach at last, due to an expanding digital environment. But in fact, the publishing and reading practices we associate with Web 2.0 have some very old precedents. One such practice is Grangerization, a bibliophile hobby that originated in the late eighteenth century. In this period, and throughout the nineteenth century, private collectors inserted various forms of ephemera into their books: prints, letters, manuscripts, receipts, clippings. The books were usually rebound to accommodate the additional pages of tipped-and pasted-in material. The Grangerized or "extra-illustrated" book turned the linear text into a unique, multi-directional network of "links" to related texts, and recast the reader as the writer's collaborator.
\end{abstract}

\section{W} E LIKE TO THINK WE INVENTED HYPERTEXT TECHNOLOGY IN THE late twentieth century, and something called social media in the twentyfirst century. We like to think that the first breakthrough enabled the creation of powerful new electronic tools, like databases - a regime of managed order to replace loss and disarray — and that the second changed the transaction between reader and writer, from uni-directional trajectory to multi-directional network. We like to think we invented this stuff, but we'd be wrong. The hypertext book that reflects and facilitates social reading made a preliminary appearance in the late eighteenth century, thanks to an Anglican parson and amateur historian named James Granger. And an extension of Granger's practice in the early twentieth century laid the groundwork for the modern full-text database.

In 1769, Granger published his Biographical History of England, from Egbert the Great to the Revolution, in which he developed a hierarchy of biographical classes important to England's national self-definition. (Predictably, kings and clergymen were at the top, poets filled the middle ranks, and women and criminals came in at the bottom.) Granger's aim was to help collectors learn the lives of those depicted in the portrait prints that, 
due to eighteenth-century advances in English engraving techniques, were finer and more plentiful than their predecessors. In this way, the collecting of prints - a new vogue that encompassed printed portraits as well as landscapes, historical scenes, and other visual genres - could be tied to the study of English history and thus could serve not only as an aesthetic hobby but also as a form of self-improvement. Granger had his History published with blank leaves to be used for notes, so that readers could record in the book references to their own print collections. Instead, it became fashionable to use Granger's book as the base text for collecting portraits that could then be set beside relevant biographies.

Grangerization, or extra-illustration, as it came to be known, developed into a bibliophile past-time that involved the insertion of many types of ephemera into books: manuscript papers as well as prints, many of which, it needs to be said, came out of other books. The extra-illustrated book is not illustrated in the usual sense; the tipped-and pasted-in additions do not visually re-create actions, things, people, or places represented in a text. Rather, as paper remnants of environments outside the book, they propose to summon those actions, things, people, or places, via documentary proxies. By multiplying its points of contact with the physical world, extra-illustrations attach a text - and its narrative, historical, descriptive, or other claims to authenticity - to a different kind of truth-regime: the reality of matter. Likewise, by augmenting the book as a physical object, the owners of books are able to exceed their status as readers and collectors; as illustrators, they also become publishers, editors, critics, or even co-authors.

Grangerization in the form practiced in the late eighteenth and early nineteenth centuries relied primarily on the juxtaposition of portraits to textual references to persons represented. In this period, collecting prints required leisure time, learning, and a certain amount of disposable income, so the desire to wed portraits to books tended to settle on fine books and historical subjects, a derivative of the antiquarianism of the eighteenth century. Collectors interested in notable contemporary figures instead might assemble and add to their books manuscript letters, signed forms, or initials on a receipt - traces of the hand to corporealize a biographical subject. But even this sort of extra-illustration complemented connoisseur interests, since books with so many additional pages would often need to be rebound or resized to accommodate large prints. A typical example of this practice is a copy of the second edition of Leigh Hunt's 1828 biography of Byron; the original two volumes, containing six plates, have been extended to five volumes by the addition of 184 plates and fourteen letters and autographs (Hunt 1828). This general pattern was still prevalent as late as 1872 , in a copy of John Forster's three-volume biography of Charles Dickens that 


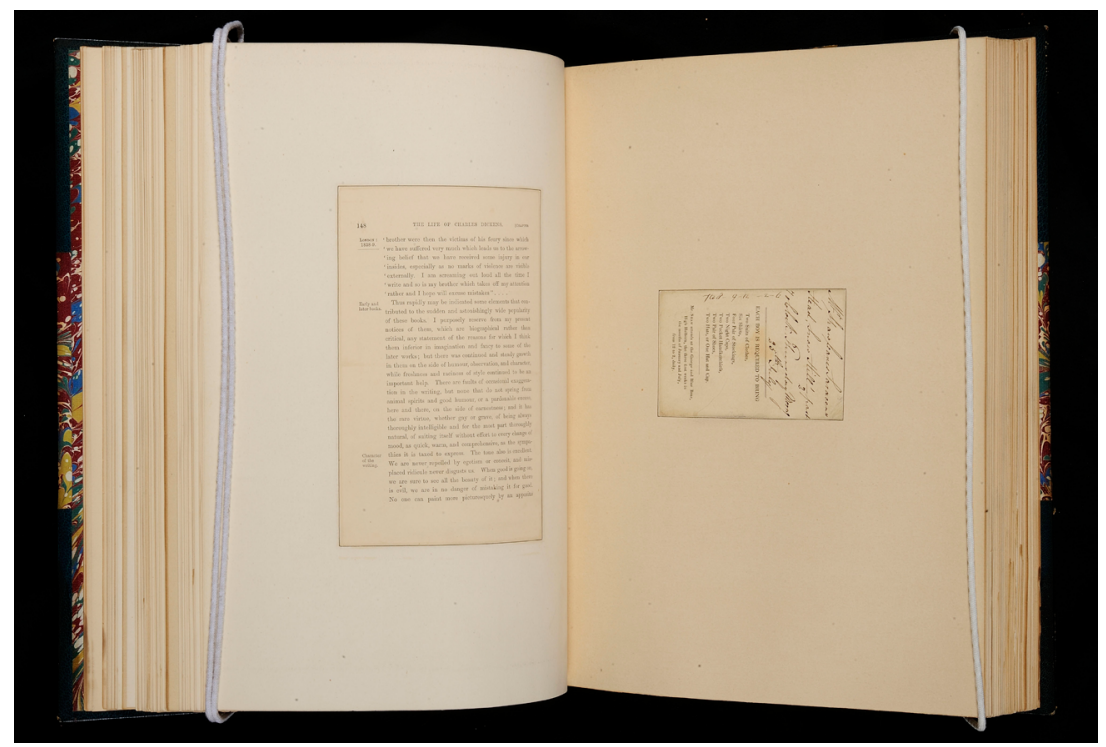

Figure 1. Advertisement for Bowes Academy, Yorkshire, the model for Wackford Squeers' Dotheboys Hall in Nicholas Nickleby. In John Forster, The Life of Charles Dickens, vol. 1 (London: Chapman and Hall, 1872). Photo by Will Kirk. From the Sheridan Libraries, Johns Hopkins University.

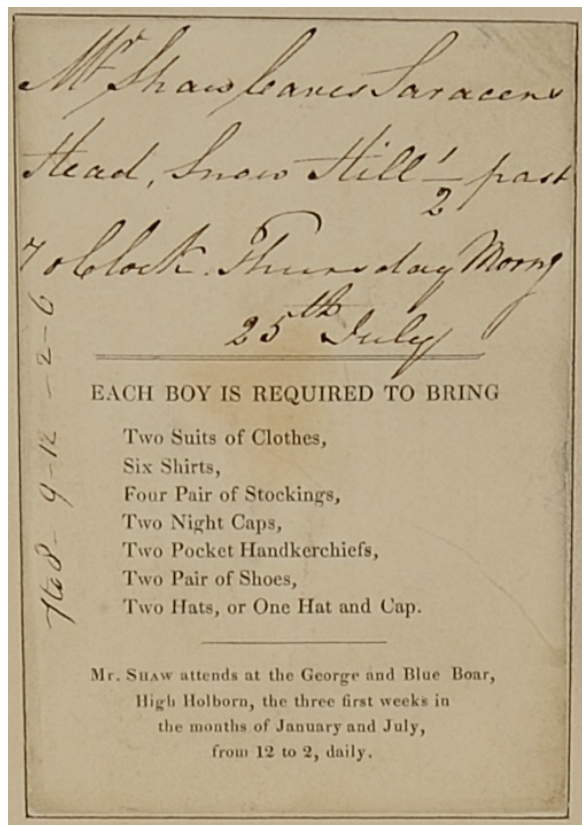


Figure 2. Title pages from earlier editions. In Alain-René Lesage, Gil Blas (Londres: Longman, Hurst, Rees, et Orme, et G. Kearsley, 1809). Photo by Will Kirk. From the Sheridan Libraries, Johns Hopkins University.

was expanded to nine folio volumes (Forster 1872). The extra-illustrator of this copy was both diligent and eclectic. Additions include broadsides for theatrical performances of "scenes from Dickens" and actor portraits; portraits of and letters by Dickens collaborators like William Harrison Ainsworth; plates from illustrated editions of Dickens' novels; a newspaper article about George Cruikshank, Dickens' long-time illustrator; even a printed advertisement with handwritten addendum on the verso for Bowes Academy, Yorkshire, headed by a certain Mr. Shaw, the model for Wackford Squeers' Dotheboys Hall in Nicholas Nickleby (fig. 1). The author is not just memorialized but monumentalized by the magnitude of the extension; unified by the text's narrative and the book's span, an accumulation of fragments becomes a sizeable corpus and proof of the subject's deserved acclaim.

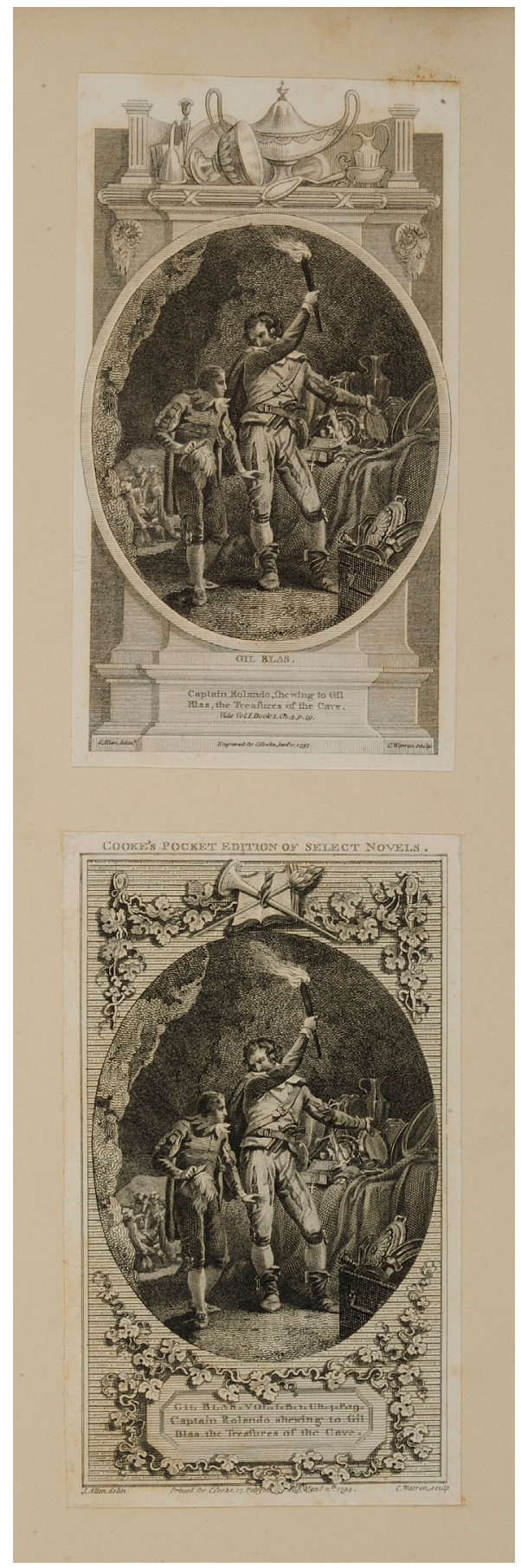


Alongside the hagiography of Hunt's Byron and Forster's Dickens, other collecting ambitions emerged, which were less about books as channels for reverence or elegance, and more about books as artifacts with their own histories. This variety of extra-illustration probably developed in part as a response to the scarcity of portrait prints and correlated spikes in prices caused by the Grangerizing fad, and in part as the bibliophilic course of the enterprise came full circle: the extra-illustrated book became a tribute to the book itself.

Consider an odd copy of Gil Blas, the Francophone picaresque novel by Alain-René Lesage, set in Spain and published in three expanding editions in 1715,1724 , and 1735 . The copy that concerns us was published in London in 1809 in French, and was extra-illustrated over the course of several decades, judging from the dates on the prints. With its many new pages, the four-volume set has grown to eight volumes. Despite the deluxe format of the original-a large-paper edition with twenty-four native copper-plate engravings, it seems designed to facilitate extra-illustration - this particular expansion is not oriented towards author-worship or tasteful display. Rather, its illustrator has turned the book into an archive of its own material genealogy, by adding in title pages and illustrations from previous and later editions (fig. 2).

This absorption of additional editions, or at least of representative morsels, may seem like a fairly simple act of appropriation - a way to have the book and eat its predecessors too. But other plates seem to comment on, or collaborate in, this appropriative performance in terms that are especially striking in relation to the text's history of authorship, reception, and publication. In 1787, the Spanish translator of Gil Blas accused Le Sage of plagiarizing a Spanish work; the French defense of its French authorship in the early nineteenth century may have contributed to its fame, as it became not just a popular favorite but, gradually, a critical favorite as well (Iknayan 1958, 370-1; Vogeley 2010, 455). Its popularity encouraged copycats in the nineteenth century, in English, French, and even Russian, several of whom went so far as to lay claim to the hero's name (IKNAYAN 1958, 371). ${ }^{1}$ In brief, as a work, Gil Blas depends on appropriation; imitative and imitated, it propels a seventeenth-century Spanish genre into nineteenth-century France and beyond. ${ }^{2}$ And our extra-illustrator seems

1. On copycat versions, see, for example, LeBlanc 1986, 340-54.

2. Its own publication history - the 1724 and 1735 editions include what were essentially Le Sage's own sequels — plus its many imitations, translations, and spurious editions, offer additional examples of the import of appropriation to “Gil Blas"; see also Cordasco 1949, 68-71. 


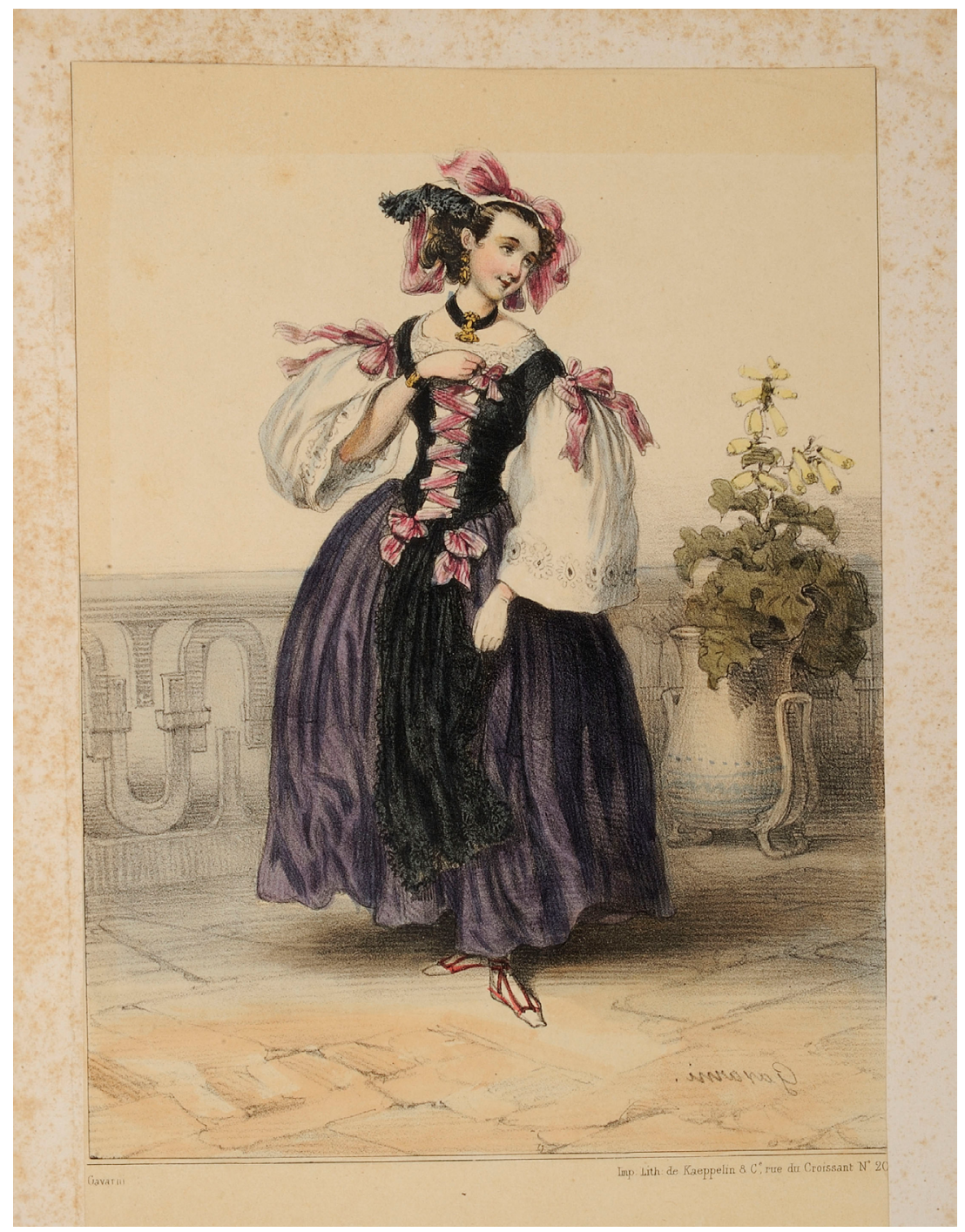

Figure 3. Paul Gavarni, "Espagnole." In Alain-René Lesage, Gil Blas (Londres: Longman, Hurst, Rees, et Orme, et G. Kearsley, 1809). Photo by Will Kirk. From the Sheridan Libraries, Johns Hopkins University.

to know it. A charming costume plate pasted in to the 1809 Gil Blas attests to these textual complications, in both national and historical dimensions, with its lithograph of a jeune fille "Espagnole" (fig. 3). Her presence in the book is undoubtedly tied to her title, perhaps identifying her with the 
young Dona Mencia, but in fact the lithograph, of a watercolor signed by Paul Gavarni, is probably one of many fashion illustrations Gavarni produced in the 1830s: "espagnole" designates a French idea of a Spanish fashion, just like Gil Blas itself.

This copy of Gil Blas also makes it very clear how Grangerization assumed its reputation as a ruinous pursuit, for books and their collectors, since many editions of Gil Blas were denuded in order to expand this one. From the time of its greatest popularity, in the early to mid-nineteenth century, Grangerization was regarded as a species of literary "destruction" or "annihilation", a "fiendish fascination" and a "monstrous practice", undertaken by "hungry and rapacious book-collectors" (Bulloch 1903, 14-15). No surprise, then, that the enthusiastic Grangerite was described as one afflicted with a psychological disorder, "a vehement passion, a furious perturbation to be closely observed and radically treated whenever it appears, for it is a contagious and delirious mania" (JACKson 1930-1, 576). At the same time, however, Grangerization borrowed a degree of legitimacy from the Victorian cult of memorialization, which, by the mid-nineteenth century, was well underway. Galvanized by technological developments in image creation, paper-making, and printing, memorial books simultaneously expressed a complicated resistance to industrialization, through an insistence on authentic contact with the past. ${ }^{3}$ Books like Historical and Literary Curiosities, professing to let history speak for itself through autographs and "reliques", reproduced the very materials that a Grangerizer would have included in the original. While it includes many "fac-similes of original documents", some of which fold out, are hand-colored, or bear plate-marks or other signatures of authenticity, its most consistent device is a page on which are paired excerpts from holograph manuscripts by historical figures with engravings depicting the subject's birthplace or residence, as in this page devoted to James Granger himself, with a text on "Iconomania" and the destruction of "old Books" (fig. 4; Sмітн 1840).

Since the engravings on these pages appear to have been tailor-made for the book, the distinction between "original document" and "facsimile" begins to erode. Indeed, this distinction is never very clear when it comes to prints, especially printed book illustrations. Clearly, both the extra-illus-

3. What I am calling Victorian memorial books, part of a larger culture of memorial objects like hair lockets and postmortem photographs, would include books of transcribed epitaphs, letters by the recently deceased, engravings of monuments, illustrated editions of, say, Thomas Gray's elegies, as well as "homemade" books like autograph albums and scrapbooks. 


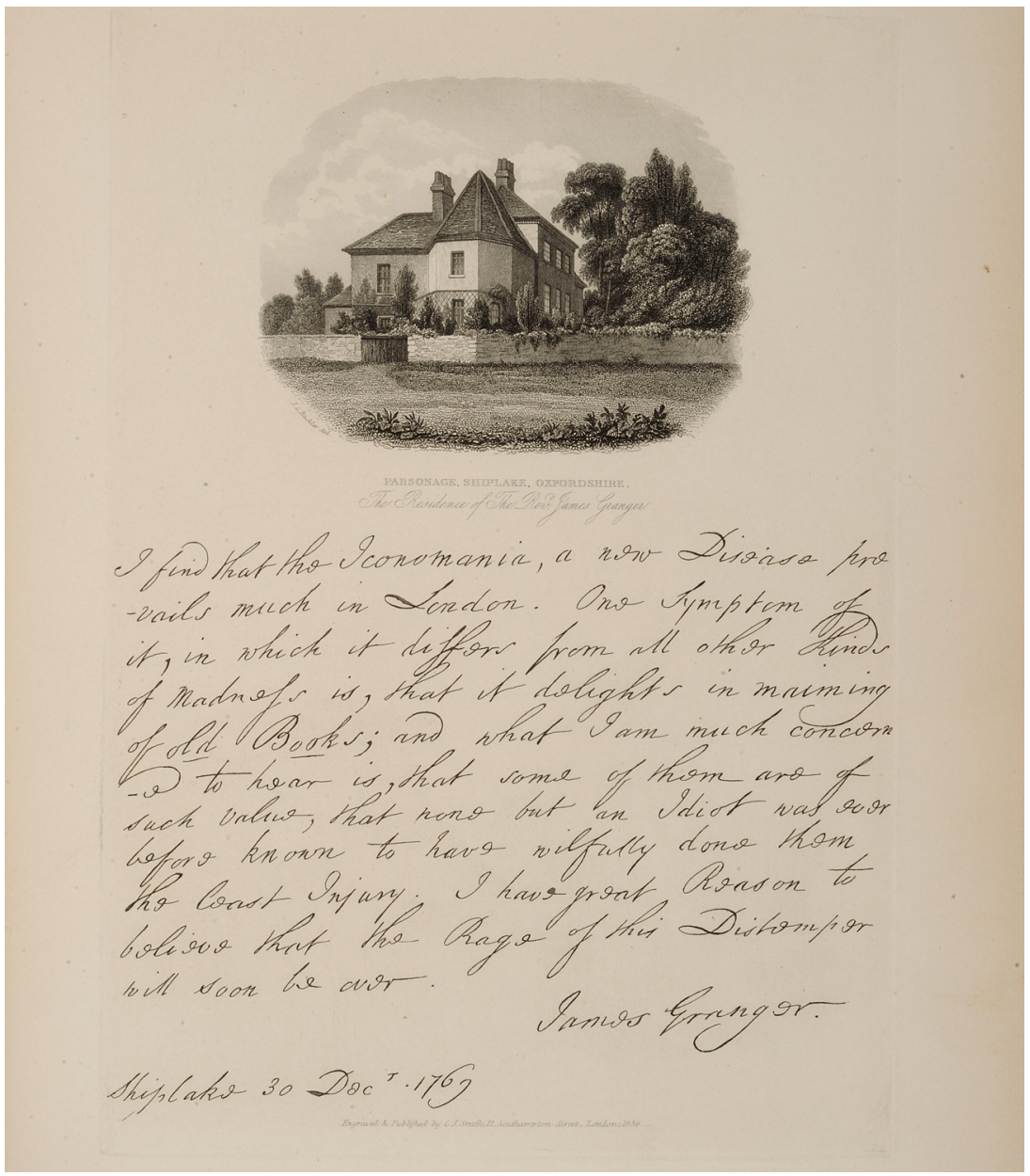

Figure 4. Facsimile of a letter by James Granger with a picture of his parsonage. In Historical and Literary Curiosities (London: Henry G. Bohn, 1840). Photo by Will Kirk. From the Sheridan Libraries, Johns Hopkins University.

trated book and the memorial facsimile were immersed in the dilemma of the original in an age of glorious reproductive surfeit.

What this encounter yielded for Grangerization is suggested by an extraillustrated copy of The Croakers. The Croakers is a collection of verse from 1819 by Fitz-Greene Halleck and Joseph Rodman Drake, who gently satirized passing cultural and political phenomena in the New York Evening Standard (later the Post); the verse was anthologized soon afterwards, but in 1860 a definitive book edition appeared, as number two in a series of 


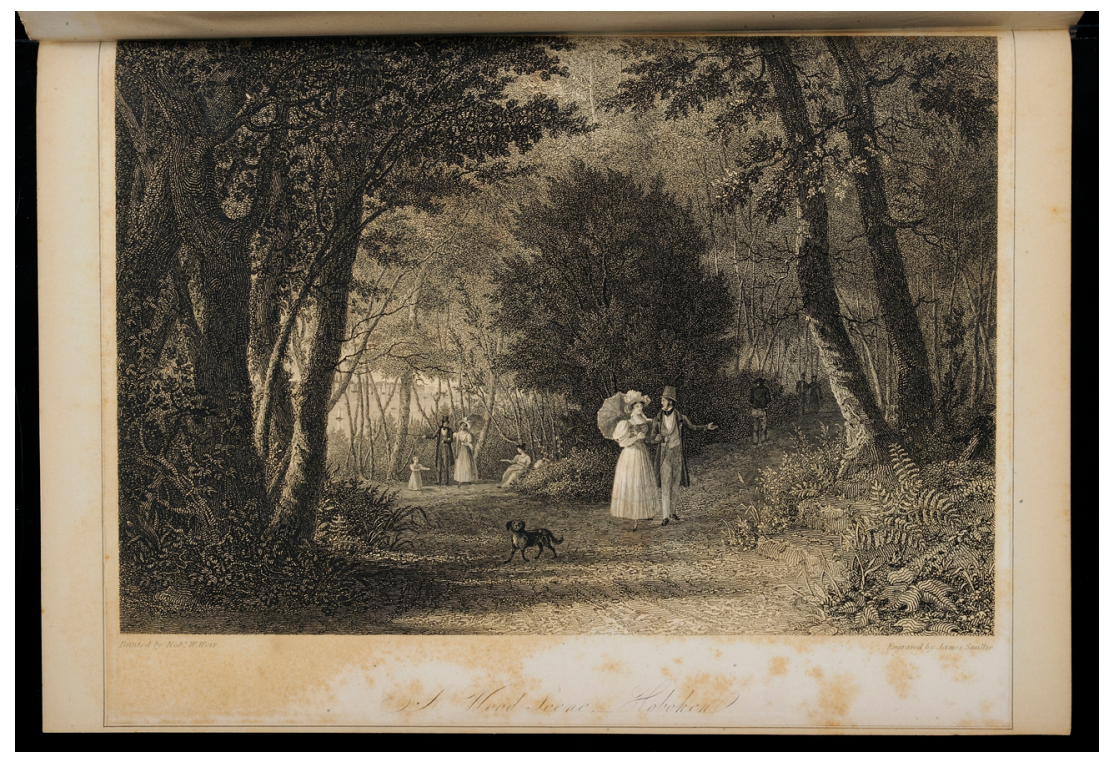

Figure 5. (detail) "Wood Scene-Hoboken" opposite a note identifying Samuel Swartout. In Joseph Rodman Drake and Fitz Green Halleck, The Croakers (New York: Bradford Club, 1860). Photo by Will Kirk. From the Sheridan Libraries, Johns Hopkins University.

publications put out by a private literary society. ${ }^{4}$ Given the topical and transitory spirit of the poems, the editors of this volume were obliged to provide extensive notes explaining the references; the notes in one copy, extra-illustrated by a member of the society, provide as many opportunities for ornamentation as the poems themselves, as in this Wood Scene-Hoboken opposite a note identifying one Samuel Swartout, who drained and embanked several thousand acres of wetlands in Hoboken in the late 1810s (fig. 5). He is named in an untitled poem by "Croaker, Junior" lamenting the decline of military heroism in a post-Napoleon world:

4. The first collection was the thirty-six page Poems by Croaker, Croaker Eु Co. and Croaker, Jun., as Published in the Evening Post (New York: Published for the Reader, 1819). The Croakers (New York, 1860) was published as number two of the Bradford Club Series, in an edition of one hundred. The Bradford Club, a New York literary society operating between 1859 and 1867, published eight books in all, on historical and literary topics. See Bradford Club Records, 1859-1868, William L. Clements Library, University of Michigan, http://quod lib.umich.edu/c/clementsmss/umich-wcl-M-229bra?view=text. See also LETter 2011, 50-71. 
Sam Swartout, where are now your Grays?

Oh! Bid again their banner blaze

O'er hearts and ranks unbroken:-

Let drum and fife your slumbers break,

And bid the Devil freely take

Your meadows at Hoboken. (9)

Instead of monumentalizing an author or cataloguing a text's publishing history, The Croakers is a curious exercise in nostalgia for the transient past as presented by a newspaper - for that most "irrelevant" feature of a nineteenth-century newspaper, the occasional poem. In The Croakers we see, in fact, a kind of reversal in the extra-illustrated book's relationship between foundational subject and ephemeral addition. Whereas newspaper extracts may have served in other books to illuminate the subject - an article appended to a page of Forster's Life of Dickens, for example - The Croakers is, in a sense, a collection of clippings turned into a foundational subject through the incorporative operations of the codex. With its double frontispiece portraits and notes, The Croakers gives its press-room poetasters a treatment that is both scholarly and wistful, attitudes at variance with the spirit of a newspaper; the extra-illustrator further alters the original, whether "original" is considered to be the newspaper issues or the 1819 pamphlet, by turning it into a treasure-book.

By the turn of the century, this dual engagement with the press of the present and a recent vanished past had become ineluctably linked. Early Schools and School-Books of New England, published in 1904 by the Club of Odd Volumes, is full of illustrations that nostalgically evoke and conflate childhood and the early days of the nation. This copy has been extra-illustrated, but it is increasingly difficult to tell which images are the additional ones, since many of the illustrations included by the publisher themselves came from mass-produced journals, printed texts, and other reproductions. Indeed, the indeterminate relationship between these two categories of image — "original" illustrations versus the later insertion of "originals" - appears to provide a new kind of enjoyment, as in this opening in which the book's reproduction of a primer's title-page provides the extra-illustrator with the opportunity to insert an actual title-page from an almost identical primer (fig. 6). Ironically, this limited edition book is described on its 1904 title page as "extra-illustrated", which means in this instance, "with lots of illustrations". 5

5. This conflation of terminology becomes increasingly prevalent in the early twentieth century, in part, undoubtedly, because extra-illustration is not a very 


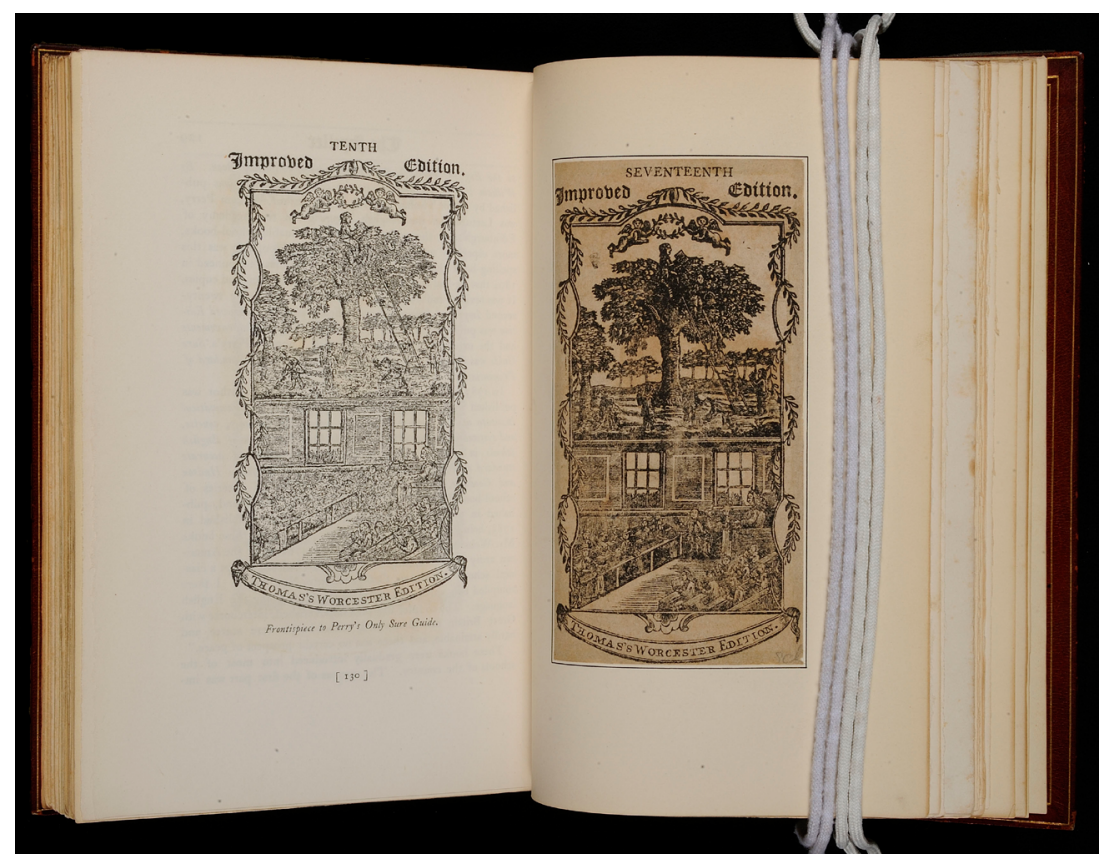

Figure 6. Extra-illustrated page next to illustration. In George Emergy Littlefield, Early Schools and School-Books of New England (Boston: Club of Odd Volumes, 1904). Photo by Will Kirk. From the Sheridan Libraries, Johns Hopkins University.

The Club of Odd Volumes is an appropriate venue for this sort of play, for it is at about this time, at the turn of the twentieth century, that extraillustration becomes more visible as a high-end hobby; its reputation simultaneously undergoes recuperation through bibliophile organizations. The annual journal The Book-lover's Almanac, for example, addresses Grangerizing in every issue from 1893 to 1897, in ways that suggest its practitioners' delight in their bad-boy reputation. They poke fun at themselves, as in this parodic cartoon of "The Book-Butcher at Home", from the 1893 issue (fig. 7) - a monomaniacal type who reappears in the cartoon "At the Binder's", where the collector tells the book-binder, "You may as well bind it to keep it shut, for I prize my books too highly to read them".

But The Book-lover's Almanac also provides how-to advice that delineates the practice's discipline and value. The self-education rationale becomes explicit in works like A Monograph on Privately Illustrated Books:

clear descriptor, but also perhaps because of the practice's change in reputation, as it is aligned not with "destructive mania" but with the aesthetics of the deluxe edition. 
A Plea for Bibliomania, published in 1882 and republished in a deluxe format in 1891. The author apologizes for his early "depredations" and calls his youthful ardor "folly", but also notes that "the knowledge incidentally acquired while engaged upon it was most thorough and was, maybe, a full or more than full compensation for the mischief otherwise done" (1882, 30). He goes on to explain that his "passion for illustrated books (which, as a general thing, are useless for study) took such direction as led to making them of more actual service, and more cyclopedic in their character; consequently, my love passed out of the purely artistic into the scientific" (1882, $32-3)$. He further notes that in his latest effort, the chief aim is not beauty but "the preservation of perishable and perishing material of value" (1882, 31). By the time J. M. Bulloch writes The Art of Extra-Illustration in 1903, this secondary rationale has become primary. Bulloch not only argues for the educational benefits of collecting and adding illustrations to printed books, but also advocates for the creation of new books made wholesale out of periodicals - topical albums of clippings, in short, that will save much precious information from the dustbin of history. In his view, "the newspaper is co-extensive with every possible aspect of human activity [. . .] but the only possible way of getting any real benefit from it is to Grangerise it on a sensible basis", not in a universal scrapbook or file, because that would simply reproduce the undesirable quantity and disorganization of material, but in thematically organized volumes (Bulloch 1903, 24-5). Bulloch's turn towards printed ephemera derives from his alarm that "side by side with the enormous output of printed matter at the present time, there is an even greater amount of destruction going on [. . .]. The thing that is very common today almost invariably becomes rare tomorrow" because nobody values it enough to preserve it $(1903,24)$. Providing detailed advice about how to carry out this task, Bulloch's method turns the Grangerizer into a one-man clipping service, archive, and index, thus reversing the oldfashioned stigma of the Grangerizer as destroyer, who becomes instead an agent of historical salvation.

The basic impulse of the Grangerite - to gain intimacy, as a reader, with the author, subject, and "body" of the book, to the point of becoming a self-appointed co-author or publisher - is most usefully situated on a continuum of desire that is both much older than Grangerization itself and very contemporary: the dream of the universal library, which Wikipedia defines as a library "containing all existing information [. . . ] all books, all works (regardless of format) or even all possible works". This is the ideal motivating, for example, the Library of Alexandria and the 1545 Bibliotheca universalis by Conrad Gesner, the "father of bibliography"; it is very much alive in current conversations about the Digital Public Library of America, 


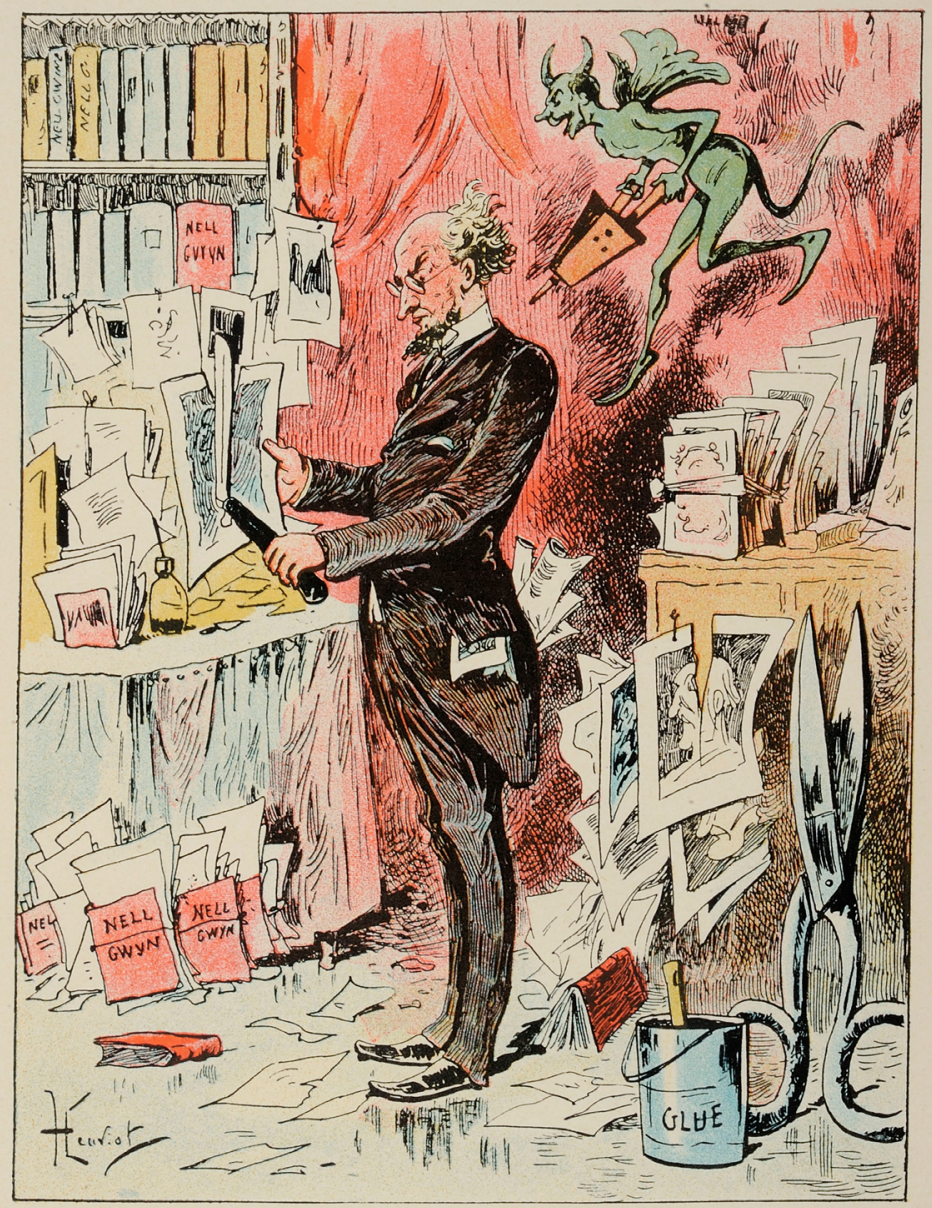

The Book-Butcher at Home.

The last of the Grangerites finishing his extra-illustrated copy of "Nell Gwynn," extended to 15,725 volumes folio by the slaughter of a book worth more than Nell Gwynn was paid for being Nell Gwynn.

Figure 7. "The Book-Butcher at Home." In The Book-lover's Almanac for the Year 1893, with Illustrations by Henriot (New York: Duprat \& Co., 1893). Photo by Will Kirk. From the Sheridan Libraries, Johns Hopkins University. 
and it is the principle that governs not only the full-text database, but the archive of digital surrogates of ephemeral materials that libraries are increasingly buying to increase access to primary sources. It is, indeed, the founding impulse behind Wikipedia itself. Not surprisingly, perhaps, a copy of Tredwell's book that has been digitized for the Internet Archive is itself extra-illustrated: here the privately illustrated book becomes fully public at last (TREDWELl 1882).

The extra-illustration practices of the early twentieth century, several decades into industrialized printing and the era of mass media communication that it launched, offer an instructive perspective from which to examine our twenty-first century information dreams for two reasons. First, they historicize our contemporary modes of self-publication, and the ways in which curatorial, editorial, and authorial roles, once distinct, are now awkwardly and indiscernibly interconnected. Secondly, they contextualize the contemporary bibliophile's distress about the decline of the codex and the values we apply to books and other printed objects: values that have to do with trade and craft, practices of attention, and reading as a vehicle for learning. Extra-illustration does not offer a salve for the bewilderment or a cure for the anxieties of the digital age; but it does allow us to see that our transition into what Robert Darnton has called the Fourth Great Information Age has a more immediate set of precedents than we often imagine.

Johns Hopkins University

\section{Works Cited}

Bulloch, John Malcolm. 1903. The Art of Extra-Illustration. In The Collector's Library, vol. 2, edited by T.W.H. Crosland, 14-15. London: A. Treherne \& Co.

Cordasco, Francesco. 1949. "Smollett and the Translation of 'Gil Blas". Modern Language Quarterly 10: 68-71.

Drake, Joseph Rodman, and Halleck Fitz-Greene. 1819. Poems, by Croaker, Croaker $\mathcal{B}$ Co. and Croaker, Jun. as Published in the Evening Post. New York: Published for the Reader.

- 1860. The Croakers. New York: The Bradford Club.

Forster, John. 1872. The Life of Charles Dickens, second edition. London: Chapman and Hall.

Hunt, Leigh. 1828. Lord Byron and Some of His Contemporaries: With Recollections of the Author's Life, and of His Visit to Italy, second edition. London: Henry Colburn.

Iknayan, Marguerite. 1958. "The Fortunes of 'Gil Blas' During the Romantic Period". The French Review 31.5: 370-7.

Jackson, Holbrook. 1930-1. The Anatomy of Bibliomania. London: The Soncino Press. 
LeBlanc, Ronald D. 1986. "Making 'Gil Blas' Russian”. The Slavic and East European Journal 30: 340-54.

Letter, Joseph J. 2011. 'New York in 1819: Defining a Local Public in the 'Croaker' Poems of Joseph Rodman Drake and Fitz-Greene Halleck". American Periodicals 21: $50-71$.

Sмitн, John Charles. 1840. Historical and Literary Curiosities: Consisting of Fac-Similes of Original Documents, Scenes of Remarkable Events and Interesting Localities, and The Birth-Places, Residences, Portraits, and Monuments of Eminent Literary Characters: With a Variety of Reliques and Antiquities Connected with the Same Subjects. London: H. G. Bohn.

Tredwell, Daniel M. 1882. A Monograph on Privately Illustrated Books: A Plea for Bibliomania. Brooklyn: Fred. Tredwell, from the California Digital Library, http:// archive.org/details/monographonpriva00tredrich.

Vogeley, Nancy. 2010. Introduction to "Two Arguments for the Spanish Authorship of 'Gil Blas", by Francisco de Isla and Juan Antonio Llorente. PMLA 125: 454-66. 